\title{
ERUPTIVE STYLE OF MESOPROTEROZOIC A-TYPE CALDERAS IN SOUTHEASTERN MISSOURI, USA
}

\section{GARY R. LOWELL}

\begin{abstract}
RESUMO ESTILOS ERUPTIVOS DE CALDEIRAS MESOPROTEROZÓICAS DO TIPO A NO SUDESTE DE MISSOURI, ESTADOS UNIDOS Vulcanismo Mesoproterozóico no sudeste de Missouri foi dominado por erupções de lavas e ignimbritos riolíticos de alta temperatura com assinatura química anorogênica. O colapso incremental da caldeira acompanhou ciclos Pliniano-Peléano-Efusivo com erupções controladas por sítios estruturalmente controlados ao longo das paredes da caldeira. Pelo menos quatro caldeiras de fluxos de cinza da classe com 20-40 km de diâmetro formaram-se a cerra de $1.48 \mathrm{Ga}$ e todas com feiçōes de modelos clássicos de caldeira em subsidência. Os aspectos coletivos das caldeiras sugerem que ciclos de saturação $\rightarrow$ ertupção explosiva $\rightarrow$ subsidência $\rightarrow$ retração $\rightarrow$ mudança de sitio tiveram papel proeminente na evolução de caldeiras do tipo A O desvio das caldeiras de Missouri dos modelos clássicos é atribuído a particularidades físicas e químicas de líquidos do tipo A e que controlam a extensão sinvulcânica do padrão de falhas regionais pré-existentes.
\end{abstract}

Palavras-chaves: caldeiras de fluxo de cinzas, estilo eruptivo, vulcanismo anorogênico, Terreno St. Frncois \begin{abstract}
Mesoproterozoic volcanism in southeastern Missouri was dominated by eruption of high temperature rhyolite ignimbrites and
lavas with anorogenic chemical signatures. Incremental caldera collapse accompanied Plinian-Peléan-Effusive cycles that were erupted at structurally controlled sites along developing caldera walls. At least four ash flow calderas in the $20-40 \mathrm{~km}$ diameter class appeared at about $1.48 \mathrm{Ga}$ and all exhibit features at variance with classic models for caldera subsidence. The collective traits of the Missouri calderas sugges that cyclic saturation $\rightarrow$ explosive ertption $\rightarrow$ subsidence $\rightarrow$ quenching $\rightarrow$ shift-of-site play a prominent role in the evolution of A-type calderas Deviation of the Missouri calderas from the classic models is attributed to the physical and chemical peculiarities of A-type melts and control of synvolcanic extension by the pre-existing regional fault pattern.
\end{abstract}

Keywords: ash flow calderas, eruptive style, anorogenic volcanism, St. Francois Terrane

INTRODUCTION The classic account of ring-fault controlled subsidence was advanced by Clough et al. (1909) to explain steep contacts between a thick Cambrian volcanic section and enclosing metamorphic rocks at Glencoe, Scotland. The salient features of the Glencoe model (i.e., cylindrical ring fault extending from surface to magma chamber and "single stroke" piston-like subsidence of a coherent block due to catastrophic magma withdrawal) were incorporated in virtually all subsequent felsic caldera models (Williams 1941; Smith \& Bailey 1968; and Lipman 1984). The success of these models, particularly in the western USA, has led some to view the Glencoe features as definitive and reject caldera status for voluminous volcanic accumulations lacking these elements. However, Walker (1984) demonstrated that flexural subsidence (ring-fracture faults absent) and incremental collapse (multiple, non-catastrophic eruptions) are more common in Quaternary calderas than are classic Glencoe features. In fact, recent work at Glencoe (Moore \& Kokelaar 1998) has shown that the classic elements are lacking even at the type locality.

Wood (1984) classifies calderas as shield calderas (e.g., Mauna Loa), stratocone calderas (e.g., Crater Lake), and ash flow calderas (e.g., Valles) and demonstrates that each morphological class is relatively consistent in terms of size, effusive products, and tectonic setting. According to Wood (1984): 1) all known calderas exceeding $20 \mathrm{~km}$ in diameter are ash flow type; 2) this caldera class is equally distributed between subduction zone and continental rift settings; and 3) slightly less than $50 \%$ of such calderas develop central resurgent plutons.

This paper describes non-classical calderas in an intraplate setting in the Mesoproterozic St. Francois Terrane of southeastern Missouri. Caldera subsidence is examined in terms of eruptive and intrusive sequences, parent melt properties, and influence of pre-existing structures. The Missouri calderas are a distinct subtype of Wood's (1984) ash flow caldera class and the style elements described here may be applicable to calderas in other anorogenic provinces, particularly those of Mesoproterozoic age.

CALDERAS IN THE ST. FRANCOIS TERRANE The St. Francois Terrane (SFT) of southeastern Missouri occupies the apex of the Ozark Dome and is the only exposure of the Eastern GraniteRhyolite Province of North America. The latter is an extensive buried belt of unmetamorphosed Mesoproterozoic igneous rocks extending from Michigan to southeastern Missouri (Lidiak et al. 1993). The SFT records three magmatic episodes occurring at approximately 1.48 ,
1.38 , and $1.33 \mathrm{Ga}$. The $1.48 \mathrm{Ga}$ event produced thick sequences of rhyolite ignimbrite and lava intruded by coeval rapakivi granite (Lowell 1991), hybrid ring plutons (Lowell \& Young 1999), and basaltic dikes (Sylvester 1984). The second cycle formed intrusions of "tin granite", magnetite-rich syenite, Kiruna-type Fe-ores (Kisvarsanyi \& Kisvarsanyi 1989), and volcanic domes (Lowell 1998). Olivine tholeiite dike swarms were emplaced across the region at $1.33 \mathrm{Ga}$ (Lowell \& Rämö 1999).

The $1.48 \mathrm{Ga}$ episode in the SFT produced significant volumes of ignimbrite and lava with A-type chemical traits and compositions ranging from metaluminous rhyolite to commendite and at least four calderas along the margins of the Missouri Gravity Low (MGL). The latter is a $90 \mathrm{~km}$ by $700 \mathrm{~km}$ northwest trending geophysical expression of a buried Proterozoic aulacogen (Guiness et al. 1982, Darnell et. al. 1995). Volcanic subsidence structures currently recognized include three overlapping elliptical calderas $20-40 \mathrm{~km}$ in diameter along the northeastern margin of the MGL and fourth fault bounded structure on the southwestern MGL margin (Fig. 1). The Butler Hill, Lake Killarney, Eminence, and Taum Sauk calderas formed during the 1.48 Ga episode and are partially bounded and dislocated by northeast and northwest trending faults (Fig. 1); they are briefly described below. The Taum Sauk Caldera preserves a nearly complete record of intracaldera processes and is discussed in more detail.

The most deeply dissected of the four structures is the Butler Hill Caldera (Sides et al.1984) which features a depth-zoned central granite massif with a granophyric roof, a transitional zone, and a deeper rapakivi facies (Lowell 1991). The central massif is circumscribed by four hybrid ring plutons (Lowell \& Young 1999) and intrudes a $1 \mathrm{~km}$ thick intracaldera ignimbrite sequence known as the Grassy Mountain Ignimbrite. Cordell (1979) proposed a subsidence structure bounded by the Simms Mountain and St. Genevieve faults based on gravity and magnetic data (Fig. 1). This structure, named the Hawn Park Caldera (Cordell 1979), is interpreted here as a dislocated segment of the Butler Hill Caldera. It is represented by the most northeasterly and deepest Precambrian exposures in the SFT (Lowell 1976, Reese \& Lowell 1998).

The southern boundary of Butler Hill Caldera overprints and partially obliterates the older Lake Killarney Caldera (Fig. 1) identified by Brown $(1983,1989)$. The southern wall of the Lake Killarney Caldera is defined by numerous occurrences of wall collapse breccia that thin northward. The major intracaldera unit is a $400 \mathrm{~m}$ thick 


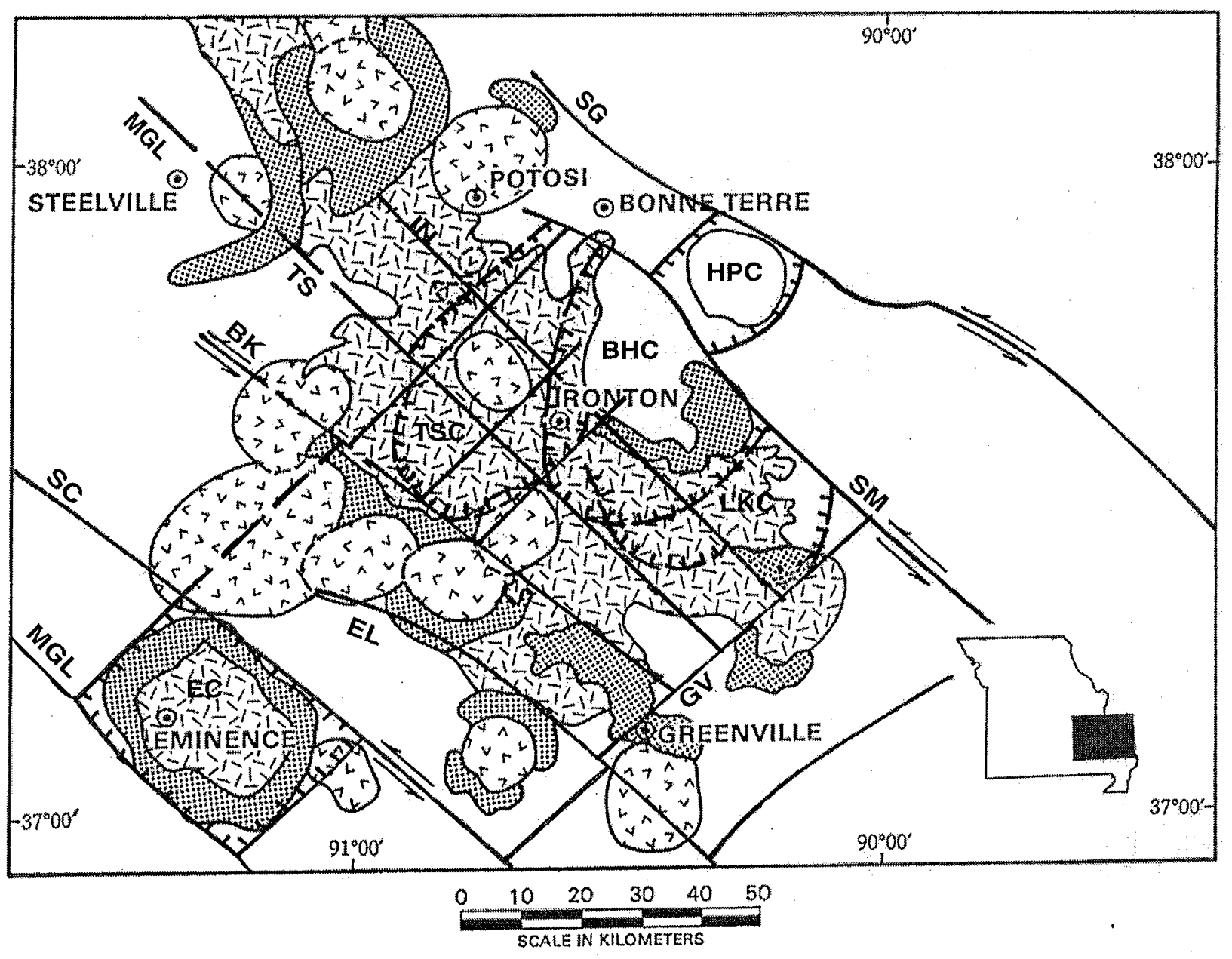

Figure I - Volcanic and structural features of the St. Francois Terrane (surface and subsurface lithology from Kisvarsanyi \& Kisvarsanyi 1989). Rock nits: vpattern $=1.38 \mathrm{Ga}$ "tin granites" (subsurface except NW of Ironton); stippled pattern $=1.38 \mathrm{Ga}$ magitetite-rich ring plutons (subsurface) and $1.48 \mathrm{Ga}$ hybrid amphibole granite (exposed in BHC); dash pattern $=1.48 \mathrm{Ga}$ rhyolite (mostly exposed); patternless area in BHC $=1.48 \mathrm{Ga}$ rapakivi massif (mostly exposed). Hachures indicate calderas walls based on thickness change, wall collapse breccia, moat sediment. BHC =Butler Hill Caldera; HPC = Hawn Park Caldera (Cordell 1979); TSC = Taum Sauk Caldera; LKC = Lake Killarney Caldera; $E C=$ Eminence Caldera; $M G L=$ Missouri Gravity Low; SC = Shannon County Fault; $E L=$ Ellington Fault; $B K=$ Black Fault; $T S=$ Taum Sauk Fault; $I=$ Ironton Fault; SM =. Simms Mountain Fault; SG = Saint Genevieve Fault; GV = Greenville Fault.

rhyolite ignimbrite known as the Lake Killarney Formation that was formerly assigned to the Butler Hill Caldera (Sides et al. 1984, Lowell 1991). Several small occurrences of F-rich granophyre north of the LKC ring structure (Fig. 1) suggest that this caldera may be intruded by a central granitic massif. At present there are no published descriptions of volcanic rocks east of the Ironton Fault in the southern SFT but relations in Fig.1 suggest they are part of the LKC offset by the Ironton Fault. However, Brown (1989) proposed that volcanic rocks in this area record an independent subsidence structure that he referred to as the Marlow Mountain Caldera.

The Eminence Caldera is located in a rectangular block bounded by the Shannon County Fault, the southwest margin of the MGL, and two northeast trending faults (Fig. 1). More than 50 isolated knobs of ignimbrite and lava and a single knob of $1.47 \mathrm{Ga}$ granophyre are exposed across an area of about $700 \mathrm{~km}^{2}$. The granophyre has an agpaitic index " 1.0 and exhibits anorogenic $\left(A_{2}\right)$, WPG, and RRG chemical signatures (Harrison et al. 2000). The volcanic rocks resemble the granophyre in age and chemical traits but have suffered pronounced $\mathrm{K}$-for-Na exchange and $\mathrm{Na}$ loss suggesting that pristine compositions were probably peralkaline. The upper volcanic sequence contains at least $800 \mathrm{~m}$ of quartz-bearing thyolite lavas and dome material resting on basal volcaniclastic and air fall deposits. It lies unconformably above a thick lower sequence of quartz-poor ignimbrites containing minor lava and air fall deposits that exhibit a pronounced northwest vertical foliation. Variable phenocryst mineralogy, steep foliation, and the tremendous thickness $(7-8 \mathrm{~km})$ of the lower sequence suggest deposition from multiple eruptive vents along an accommodation zone (Bosworth 1987) of a developing rift structure (Harrison et al. 2000).

TAUM SAUK CALDERA Volcanic rocks in the western SFT were first mapped in detail by R.E. Anderson (1962) who concluded that they record a simple structural sag. Subsequently, J.E. Anderson et al. (1969) reinterpreted the thick volcanic succession as an intracaldera sequence and presented evidence for the existence of the Taum Sauk Caldera (TSC). The caldera concept was challenged by R.E. Anderson (1970) but supported by Berry \& Bickford (1972) and Sides (1981) who located a segment of the ring fracture on Ketcherside Mountain (Fig. 2). Sides et al. (1981) reviewed the controversy, noting that one argument presented by J.E. Anderson et al. (1969) was based on erroneous age data, but concluded that the caldera concept was valid.

Recent reviews by Lowell $(1999,2000)$ describe the Taum Sauk Caldera (Fig. 2) as a non-classical subsidence structure that collapsed incrementally during the $1.48 \mathrm{Ga}$ volcanic episode. The caldera is 30 $\mathrm{km}$ in diameter and encloses about $600 \mathrm{~km}^{3}$ of A-type rhyolite ignimbrites, lavas, and air fall units. This intracaldera sequence is neither domed nor cut by coeval plutons but is modified by Phanerozoic reactivation of Precambrian faults and erosion. Intracaldera volcanic units approximate $7 \mathrm{~km}$ in total thickness but the maximum stratigraphic thickness at the depocenter is only about 1.5 


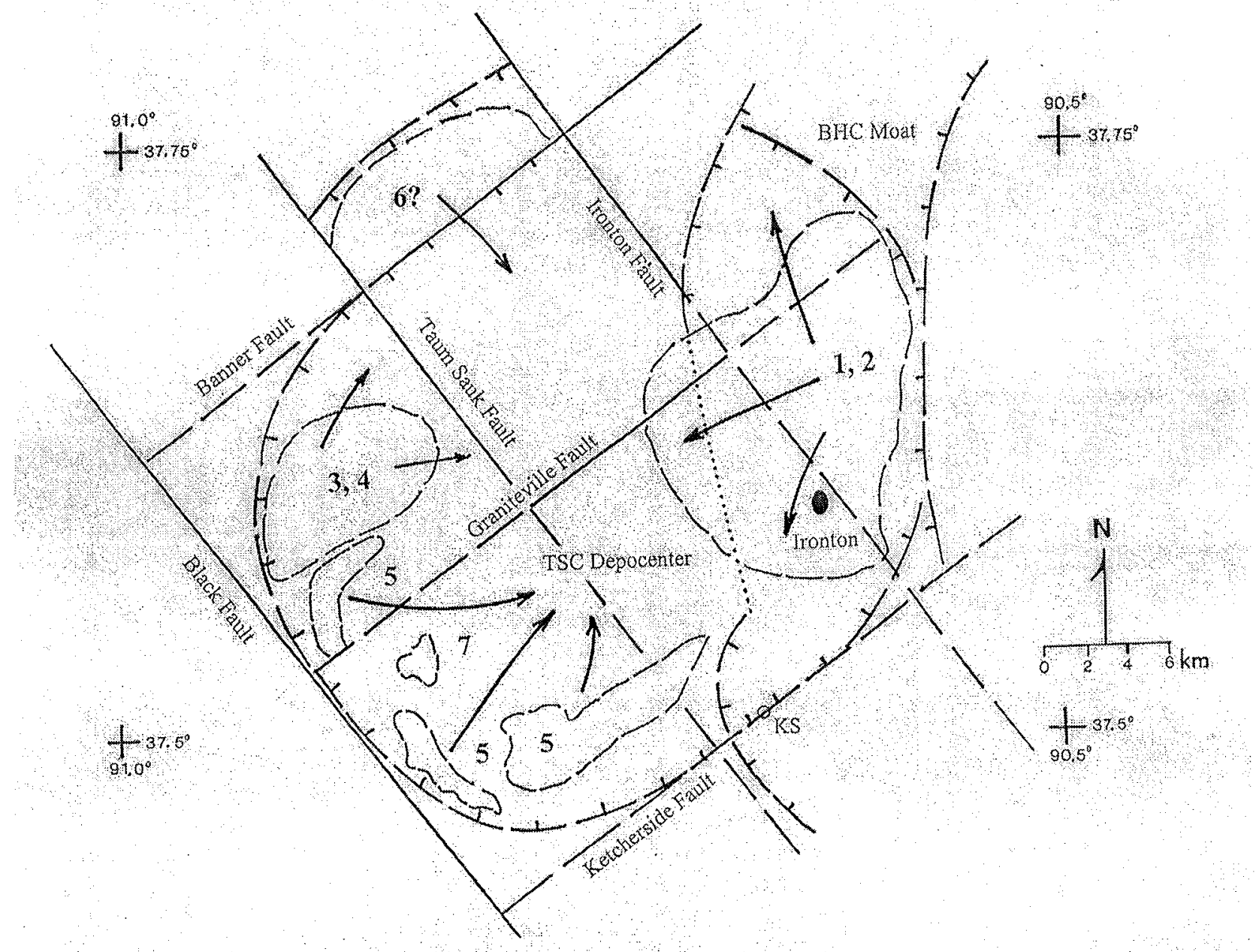

Figure 2 - Volcanic and structural features of the Taum Sauk Caldera. Opposed hachures on east delineate moat of older Butler Hill Caldera; concentric hachures mark walls of Taum Sauk Caldera (same criteria as Fig. I). Heavy dashed and solid straight lines show prevolcanic fault system exploited by synvolcanic extension. Heavy dashed curved lines enclose vent sites of intracaldera sequence; arrows indicate transport and dip. Numbers indicate eruptive synvolcanic extension. Heavy dashed curved lines enclose vent sites of int lithic-rich ignimbrites, volcaniclastics and lavas unconformably deposited on BHC sequence: $I=I$ ron Mountain Felsite-Ironton Hollow Rhyolite (1400 mof lithic-rich ignimbrites, volcaniclastics and lavas with I); 3) Buck Mountain S/uttin sequence); $2=$ Shepard Mountain-Cedar Bluff-Pond Ridge Rhyolites ( $1310 \mathrm{~m}$ of crystal-rich ignimbrite conformable with 1$) ; 3$ ) Buck Mountain Shatim Formation-Wildcat Mountain Rhyolite (1000 m of air-fall fuff followed by $1000 \mathrm{~m}$ of crystal-poor ignimbrites); $4=$ Bell Mountain Rhyolite-Royal Gorge Rhyolite

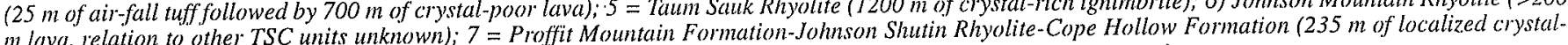
m lava, relation to other TSC units unknown); $7=$ Proffit Mountain Formation-Johnson Shutin Rhyolite-Cope Hollow Form

$\mathrm{km}$. This thickness disparity is the result of venting along developing caldera walls and centripetal flow toward the depocenter (Fig. 2). Berry's (1976) detailed account of TSC stratigraphy, viewed in the context of "normal ignimbrite sequences" (Sparks et al. 1973), reveals 5 Plinian-Peléan-Effusive episodes. These small to moderate volume cycles were mostly initiated by air fall tuff eruptions, reached maximum intensity during emplacement of crystal poor ignimbrites, and concluded with crystal rich lava flows. Each cycle produced a depositional fan around its source extending 4-12 km toward the depocenter. Eruptive activity shifted along the controlling faults as indicated in Fig. 2.

The last of the 5 major eruptive events related to the TSC produced approximately $60 \mathrm{~km}^{3}$ of crystal-rich ignimbrites known as the Taum Sauk Rhyolite (TSR). The large volume of this unit is anomalous in terms of caldera chronology and absence of antecedent air fall deposits and subsequent lava flows. Possibly these rocks record migration of a new batch of magma into the zone tapped by active vents. On-going chemical studies of the TSC volcanic sequence may clarify this uncertainty. The TSR was erupted from at least 3 vent sites along the southwestern caldera wall (Fig. 2) and attained a maximum thickness of about $1200 \mathrm{~m}$ in the central caldera. The thickness and location of the depocenter are important because they indicate that morphological development of the caldera was well advanced when the TSR eruptions occurred. The gentle synclinal configuration of the intracaldera sequence indicates continued subsidence after cessation of TSR eruptions.

TSC events concluded with small-scale eruptions of crystal-rich ignimbrite, air falls, and deposition of minor fluvial and lacustrine sediments. The latter include volcaniclastic sediments enclosing thin stromatolitic carbonate horizons in the Proffit Mountain area and along the southeastern caldera wall at Ketcherside Mountain (Fig. 2) where $\mathrm{Au}-\mathrm{Cu}$ bearing scapolite skarn replaces carbonate strata.

SUMMARY AND CONCLUSIONS Mesoproterozoic volcanism in southeastern Missouri was dominated by ring fracture eruptions of high temperature, high silica rhyolite ignimbrites and lavas with anorogenic chemical traits. At least 4 ash flow calderas in the 20-40 $\mathrm{km}$ diameter class appeared at about $1.48 \mathrm{Ga}$ and all exhibit features at variance with the classic model for caldera subsidence. The collective traits of the Missouri calderas indicate that cyclic saturation $\rightarrow$ explosive eruption $\rightarrow$ subsidence $\rightarrow$ quenching $\rightarrow$ shift-of-site played a prominent role in their formation. Individual calderas were filled by low to medium volume Plinian-Peléan-Effusive cycles erupted from multiple vent sites. Shifting eruptive loci linked these sites to produce a defacto ring fracture zone circumscribing a zone of piecemeal subsidence. Deviation from the classic model is attributed to: 1) the 
physical and chemical peculiarities of A-type melts (Eby 1990) and 2) control of synvolcanic extension by the pre-existing orthogonal fault pattern. The most important style elements of the Missouri calderas are:

1 - A-type melts $\left(\approx 900^{\circ} \mathrm{C}\right.$, low $\mathrm{H}_{2} \mathrm{O}$, high $\mathrm{F}$, low viscosity) approximate granite minimum composition at low $\mathrm{P}$; narrow compositional range of eruptive products precludes magma chamber zoning except for volatiles;

2 - Magma ascent was nearly isothermal (eruptive $\mathrm{T} \approx$ liquidus $\mathrm{T}$ ) so early eruptives are crystal poor;

3- Incremental subsidence is due to multiple eruptive events of small to intermediate volume rather than single-stage, piston-like subsidence related to single large volume catastrophic eruptions;

4 - Reduced eruptive volumes are related to high magma ascent that permits pyroclastic eruptions shortly after melt saturation;

5- Pre-existing faults were exploited by synvolcanic extension and exert significant control on vent location and subsidence geometry;

6 - Degassing forced eruptive activity to shift to new sites above saturated melt; sub-vent "quench granophyres" impose barriers to further eruption unless rapid influx of meteoric water remelts the barrier;
7 - Shifting eruptive loci are linked by pre-existing/synvolcanic faults to define a ring fracture zone that mirrors the orthogonal fault pattern;

8- Early eruptive products vent from structurally controlled sites along developing caldera walls with centripetal flow toward depocenter of developing caldera;

9- Late hybrid ring plutons reflect renewed influx of basalt after most silicic melt is solid;

10 - Central doming by melt resurgence is observed in only one Missouri caldera

11 - Wall-collapse breccias composed of early volcanic products (including basalt) were transported toward the depocenter along listric boundary faults; fluvial volcaniclastics and lacustrine stromatolitic carbonates were deposited in small intracaldera basins.

Acknowledgements The author is grateful for the opportunity to participate in the First Symposium on Volcanism and Associated Environments. The organizers and scientific committee are congratulated on a symposium of high scientific merit convened at a site of outstanding beauty and hospitality. Special thanks go to Adriane Machado and Márcia Barros Pinho for their many kindnesses during my stay in Brazil. To two anonimous referees of Revista Brasileira de Geociencias for the review and suggestions to the manuscript.

\section{References}

Anderson J.E., Bickford M.E., Odom A.L., Berry Junior A.W. 1969. Some age relation and structural features of the Precambrian volcanic terrane, St. Francois Mountains, southeastern Missouri. Geological Soc. America Bull., 80:1815-1818.

Anderson R.E. 1963. Pyroclastic flows of the Missouri Precambrian (abstract). Geological Soc. America Special Paper, 73:105.

Anderson R.E. 1970. Ash-flow tuffs of Precambrian age in southeast Missouri. Missour Geological Survey Report of Investigations, 46:1-50

Berry Junior $\AA$.W 1976. Proposed stratigraphic column for Precambrian rocks, western St. Francois Mountains, Missouri. Missouri Geological Survey Report of Investigations 61:81-90.

Berry Junior A.W. \& Bickford M.E. 1972. Precambrian volcanics associated with the Taum Sauk Caldera, St. Francois Mountains, Missouri, USA. Bulletin Volcanologique, 36:308-318

Bickford M.E., Sides J.R., Cullers R.L. 1981. Chemical evolution of magmas in the Proterozoic terrane of the St. Francois Mountains, southenstern Missouri, J. Field, petrographic, and major element data. J. Geophys. Research, 86(B11):10365-10386.

Bosworth W. 1987. Off-axis volcanism in the Gregory rift, east Africa: implications for models of continental rifting. Geology, 17:397-400.

Brown V.M. 1989. Geological overview of the southern St. Francois Mountains, Missouri. In: Olympic Dam-Type Deposits and Geology of the Middle Proterozoic in the St. Francois Mountains Terrane, Missouri. Economic Geology Guidebook Series, 4:93 109

Brown V.M. 1983. The Precambrian volcanic stratigraphy and petrology of the Des Aic NE 75 Minute Quadrangle south central St. Francois Mountains, Missouri. Unpublished $\mathrm{Ph} . \mathrm{D}$ dissertation, Univ Missouri-Rolla, 190p.

Clough C TH Maufe H B. Bailey E B 1909 The cauldron subsidence of Glencoe and the associated igneous phenomena. Geological Soc. London Quaterly Journal, 65:611678

Cordell L. 1979. Gravity and aeromagnetic anomalies over basement structure in the Rolla quadrangle in the southeast Missouri lead district. Economic Geology; 74:1383-1394. quadrangle in the southeast Missouti lead district. Economic Geology, 74:1383-1394.
G.N. 1990. The A-type granitoids: a review of their occurrence and chemical G.N. 1990. The A-type granitoids: a review of their occurrence and

characteristics and speculations on their petrogenesis. Lithos, 26:115-134.
Darnell B.D., Al-Shukri H.J., Lowell G.R. 1995. Density distribution model of the upper crust beneath the St. Francois Igneous Terrane and the Missouri Gravity Low. Geological Soc. America Abstracts with Progrants, 27(6):A-193.

Guiness E.A., Arvidson R.R., Strebek J.W., Schulz K.J., Davies G.F., Leff C.E. 1982 Identification of a Precambrian rift through Missouri by digital image processing geophysical and geological data. $J$. Geophysical Research, 87 (B10):8529-8545.

Harrison R.W. Lowell G.R. Unruh D.M. 2000. Geology geochemistry, and age of a major outlier of the St. Francois Terrane, southeast Missouri. Geological Soc. America Abstracts with Programs (South-Central Section, in press).

Kisvarsanyi G. \& Kiisvarsanyi E.B. 1989. Precambrian geology and ore deposits of the southeast Missouri iron metallogenic province. In V.M. Brown. E.B. Kisvarsany southeast Missouri iron metallogenic province. In: V.M. Brown, E.B. Kisvar'sanyl and R.D. Hagni (editors). "Olympic Dam-Type" Deposits and Geology of Middle Proterozoic Rocks in the St. Francois

Lidiak E.G., Bickford M.E., Kisvarsanyi E.B. 1993. Proterozoic geology of the eastern midcontinent region. In: Reed J. et al. (editors). Geology of North America Volume C 2. Precambrian Conterminous U.S. Geological Society of America: 259-270
Lipman PL 1984. The roots of ashflow calderas in western North America: windows into the tops of granitic batholiths. J. Geophysical Research, 89(B10):8801-8841

the tops of granitic batholiths. J. Geophysical Research, 89(B10):8801-8841. Missouri, USA Bolotim de Resumos Simposio Sobre Vulconismo e Ambientes AsMissouri, USA. Bolotim de Resumos,

Lowell G.R. 1998. Emplacement of a vitrophyric lava dome in the St. Francois Terrane of Missouri: constraints imposed by amphibole. Field Guide and Proceedings Volume Proterozoic Granite Systems of the Penokean Terrane of Eastern Wisconsin (IGCP Project-426): $157-158$

Lowell G.R. 1991. The Butler Hill Caldera: a mid-Proterozoic ignimbrite-granite complex. Precambrian Research 51:245-263.

Lowell G.R. 1976. Petrography of Precambrian rocks in the Hawn State Park area, Ste. Genevieve County, Missouri. Missouri Geol Survey Report of Investigations, 61:140-148.

Lowell G.R. \& Ramo O.T. 1999. Petrology and geochemistry of the Shepard Mountain Gabbro Geological Soc. America Abstracts with Programs 31(5):A-32.

Lowell G.R \& Young G.] 1999 . Interaction of coeval mafic and felsic melts in the $S t$ Francois Terrane of Missouri, USA. Prec. Research, 95:69-88.

Moore I. \& Kokelaar P. 1998. Tectonically controlled piecemeal caldera collapse: a case study of Glencoe volcano, Scotland. Geological Soc. America Bull., 110: $1448-1466$

Reese J.F. \& Lowell G.R. 1998. The Hawn Park Gneiss, Mesoproterozoic St. Francoi Terrane, southeastern Missouri: a deformed, migmatized xenolith. Geological Soc. America Abstracts with Programs, 30 (7):A-96.

Sides J.R. 1981. Geology of the Ketcherside Mountain area, southeastern Missouri and the source of the Grassy Mountain Ignimbrite. Geological Soc. America Bull., 92: 686693

Sides J.R. Bickford M.E., Shuster R.D., Nusbaum R.K. 1981. Calderas in the Precambrian terrane of the St. Francois Mountains, southeastern Missouri. J Geophlys. Res, 86(B 11):10349-10364.

Smith R. L. \& Bailey R.A. 1968. Resurgent cauldrons. Geological Soc. America Memoir, 111:613-662.

Sparks R.S.J., Self S., Walker G.P.L, 1973. Products of ignimbrite eruptions. Geology 1:115-118.

Sylvester P.J. 1984. Geology, petrology, and tectonic setting of the mafic rocks of the 1480 Ma old granite-rhyolite terrane of Missouri, USA. Unpublished Ph.D. dissertation, Washington University (St. Louis), 589p.

Walker G.P.L. 1984. Downsag calderas, ring-faults and caldera sizes. J. Geophys. Res. 89(B 10):8407-8416.

Williams H. 1941. Calderas and their origin. Bull. Dept. Geological Sciences Univ. California, 25:239-346.

Wood C.A. 1984. Calderas: a planetary perspective: J. Geophys. Res., 89 (B10):8391-8406.

Manuscrito A-1136 Recebido em 1 de dezembro de 1999 Revisão do autor em 20 de maio de 2000 Revisão aceita em 25 de maio de 2000 